\title{
ДЕОНТОЛОГІЧНА ПРАВОСВІДОМІСТЬ ЮРИСТА У ТРУДОВІЙ СФЕРІ
}

\author{
РУДАНЕЦЬКА Оксана СТефанівна - кандидат юридичних наук, доценТ, \\ доцент кафедри права факультету управління, економіки та права Львівського \\ національного аграрного університету
}

УДК $34: 165.12$

DOI 10.32782/LAW.UA.2021.3.24

Статья посвящена деонтологическому правовому сознанию юриста. Указано, ито правосознание расширяет возможности лица при реализаиии правовых норм. Правосознание помогает пропагандировать сознание правовой культурь, участвует в бормировании законов и верховенства права.

Обобщенно, что правовое сознание определяется как процесс, посредством которого люди осмысливают свой опьлт, опираясь на правовъге категории и концепции. Его в научных кругах принято понимать как форму отражения правовых явлений, которое включает психические, интеллектуальнье, эмочиональные и волевъе процессы и состояния. Указано, ито деонтологическое правосознание бормируется путем накопления и бункиионального взаимодействия многих элементов.

Мотивировано, что юридическая деонтология является теоретической основой для создания актов деонтологического содержания путем имплементации въгских норм профессиональной этики. Они имеют двойное значение: с одной сторонъ, деонтологическое правосознание в трудовой сфоре обогащает личность юриста, помогает должно реализовълвать свои профессиональньле функиии, защищать интересь прав и свобод граждан. С другой сторонь, оно призвано унибицировать трудовъе отношения среди юридических специалистов, сделать профессию юриста моральной, доброй, справедливой.

В заключении указано, что кодексъ профессиональной этики имеют такие сочиальнвие функиии и цели: определяют этические указания и лучшие практики организачии, которьхх следует придерживаться для честности, добропорядочности и профессионализма; содержат нормъ превентивного и карательного характера, то есть для членов организачии нарушения этического кодекса может привести к санкциям, включая освобождение. Кодексы содержит приниипь, сбормулированнье как заявления об ответственности, основаннъие на понимании того, что общественное благо всегда является первоочередной; регулируют деловое поведение в пределах профессии и с другими членами общества; определяют пробессиональные изенностные категории; способствуют соблюдению профессиональной и служебной дисииплинъ; способствует очищению профессии, увеличивая доверие к специалистам в области права, легитимизируют юриспруденцию и практическую юридическую деятельность.

Ключевые слова: деонтология, правосознание, профессиональная этика юриста, кодексъи профессиональной этики, трудовъе отношения, корпоративнъие нормь права.

\section{Постановка проблеми}

Оновлення правового поля, реформування юридичних норм, зміна соціально-правової реальності зумовлюе потребу формування ефективного класу правозахисників. Звертаємо увагу, що тут йде мова не тільки про фахівців у галузі права, але й про представників влади, державних службовців, громадських діячів. Однак, усе ж професійний клас юристів формує основну па- 


\section{Філософія та психологія права}

радигмальну сутність правової реальності в кожній державі. Вони дотичні як до формування державної політики, так і до правореалізаційної діяльності. «В умовах розбудови незалежної Української держави постала нагальна потреба у висококваліфікованих фахівцях у сфері права, які б на високому рівні відстоювали права, гідність і честь людини, були носіями правди та справедливості, гуманізму та милосердя, служили еталоном виконання свого професійного обов'язку правника» [1, с.5].

Вагому роль у цьому ключовому правовому механізмі відіграє правова свідомість. Вона розширюе можливості особи щодо реалізації правових норм. Правосвідомість допомагає пропагувати свідомість правової культури, бере участь у формуванні законів i верховенства права. Тому важливим науковим завданням є дослідження деонтологічних проявів правової свідомості юриста.У межах цього наукового доробку неможливо розкрити всі аспекти деонтологічноїх правосвідомості, оскільки поняття є доволі масштабним. Тому метою наукової статті є аналіз деонтологічної правової свідомості юриста у трудовій сфері суспільних відносин.

\section{Стан дослідження}

У відчизняній доктрині теорії та філософії права неодноразово розглядалась проблема правосвідомості та іiі аналізу. Питання про природу, елементи, значення правосвідомості знайшли безпосереднє відображення в дослідженнях О. В.Большакової, В. О. Котюка, В. П. Малахова, А. Д. Мостовщикова,E. В. Назаренко, Г. С. Остроумова, С.С.Сливки, Й. Ю. Фарбера, В. А. Чефранова, ᄉ. С. Явича тощо. Однак проблеми деонтологічної правосвідомості юриста у трудовій сфері залишилися поза активною увагою науковців.

\section{Виклад основних положень}

Правова свідомість визначається як процес, за допомогою якого люди осмислюють свій досвід, спираючись на правові категорії та концепції. Її в наукових колах прийнято розуміти як форму відображення правових явищ, яка включає психічні, інтелектуальні, емоційні й вольові процеси та стани. Уза- гальнюють, що «специфічною формою свідомості є правова свідомість (правосвідомість) - система відбиття правової реальності в поглядах, теоріях, концепціях, почуттях, уявленнях людей про право, його місце та роль щодо забезпечення свободи особи й інших загальнолюдських цінностей» [2].

У свою чергу, «деонтологічна сфера представляє собою складну сітку взаємних вимог та зобов'язань особистості й суспільства, суспільства і колективу, колективу й особистості. Ці відносини мають належний характер, тобто вимагають від особистості способу життя, який відповідав би потребам суспільства. У загальному вираженні деонтологічні цінності є особливим видом духовних явищ, які задовольняють потреби культури в регулюванні соціальних відносин і вчинків людей» [3].

Юридична професія, з нормативної точки зору, повинна полягати в оволодінні нормативно-правовою інформацією та передбачати можливість застосування знань на практиці. Проте сучасне суспільство не може існувати в таких вузьких рамках. Право - це лише один з можливих регуляторів суспільних відносин. Не можна відкидати і додаткові норми, принципи, правила поведінки, що існують у соціумі, зокрема мораль, релігію, корпоративні норми, культурні парадигми тощо. Отож нині слід говорити про відхід від «сухого» нормативного легістського підходу у професії юриста і розширення іï шляхом імплементації морально-ціннісних досягнень людства. Саме такий процес може забезпечити деонтологічне спрямування правосвідомості.

За твердженням корифея української філософії права С.С. Сливки, «деонтологічна правосвідомість юриста - це результат його правосвідомості, сформований під впливом правової інформаційної культури, при виконанні службового обов'язку» [4, с.107].

Як стверджують В.Д. Гапотій, О.Г. Мінкова, «деонтологічна правосвідомість - це інтелектуальна власність юриста, оскільки вона пов'язана 3 інтелектом та моральними принципами; це конкретизація його правосвідомості, що відповідає одній із функцій юридичної деонтології» [5, с.31]. 
Деонтологічна правосвідомість формується шляхом накопичення та функціональної взаємодії багатьох елементів. Більшість науковців погоджуються 3 тим, що обов’язковими складовими ії повинні бути: правові знання, високий рівень поваги до права, політико-правова та соціальна активність особи. Вказані елементи забезпечується через суб'єктивні індивідуальні виміри інтелектуальних та емоційних процесів і станів.

Деякі науковці розширюють склад елементів, зокрема, В.М. Кравчук до них відносить деонтологічні принципи, які розуміє як «вихідні аксіоматичні вимоги до професійної діяльності юриста, що виконують функції соціальних орієнтирів його поведінки в різноманітних ситуаціях. Принципи юридичної практичної діяльності у концентрованому вигляді визначають їі основні властивості, $є$ похідними від принципів права, конкретизують і деталізують їх. Вони конкретизуються у нормативно-правових актах, професійних деонтологічних кодексах, правосвідомості юристів і суспільства в цілому; є критеріями оцінки власне самої діяльності, їі результатів, рівня професійної культури юристів, основою їх юридичного професійного практичного мислення; забезпечують ціннісноорієнтаційний, результативний, психологічний, інформаційний вплив на взаємовідносини юристів з іншими суб'єктами, ведення юридичних справ, прийняття рішень, особливо у випадках, не врегульованих правовими, корпоративними, деонтологічними та іншими професійними нормами» [6].

Первинним серед елементів усе ж залишається правове знання та правове мислення. Чупринський Б.О. мотивує, що «юрист зобов'язаний володіти високорозвиненим правовим мисленням, бути здатним до швидкого аналізу, логічного виведення суджень, потрібних для прийняття правильних правових рішень. Розвинуте теоретичне мислення - це здатність особистості до засвоєння на високому рівні правових знань, узагальнення, розуміння наукових основ і принципів розвитку тих чи тих правових знань; уміння передбачати залежність і закономірність існування суттєвих зв'язків між правовими явищами» [7, с.65].
Для здобуття належного рівня деонтологічної культури вагомою $є$ правова освіта та правове виховання. «Найважливішу роль у розвитку правової свідомості юристів відіграє раціонально побудована система етичного, трудового, правового, інтелектуального виховання, що здатна забезпечити формування в майбутніх фахівців активного життестверджуючого менталітету, перетворення культури правової поведінки на невід'ємну властивість своєї особистості» [8, с.22].

Правове виховання повинно здійснюватися комплексно. Серед усіх видів виховання одним 3 найсуттєвіших $\epsilon$ виховання у трудовій сфері. Зокрема саме професійна спільнота створює професійні (корпоративні норми морально-етичного характеру. У цьому й проявляється особливість деонтологічної правосвідомості в трудовій сфері. Вона грунтується на корпоративних правилах поведінки морально-етичного характеру.

Юридична деонтологія є теоретичною основою для створення актів деонтологічного змісту шляхом імплементації високих норм професійної етики. Вони мають подвійне значення: 3 одного боку деонтологічна правосвідомість у трудовій сфері збагачує особу юриста, допомагає належно реалізовувати свої професійні функції, захищати інтереси прав та свобод громадян. 3 іншого боку, деонтологічна правосвідомість покликана уніфікувати трудові відносини серед юридичних фахівців, зробити професію правника моральною, доброю, справедливою.

Особливість корпоративного (професійного) регулювання полягає у поєднанні правових та моральних норм у деонтологічних кодексах професійної поведінки, призначених для юристів чи правоохоронців.

Аналізуючи «акти деонтологічного змісту», М. Пендюра розглядає їх як нормативну основу юридичної деонтології, виокремлюючи, зокрема, такі: «етичні або деонтологічні кодекси (правила поведінки) професійних груп юристів, які прийняті в державі - кодекси національних об'єднань (корпорацій) юристів, етичні або деонтологічні кодекси, канони (правила поведінки) юристів, які затверджені як міжнародні стандарти - кодекси міжнародних об'єднань юристів; законодавчі і підзаконні нормативно-правові акти 


\section{Філософія та психологія права}

держави в тій їх частині, у якій містяться нормативні приписи етичного (деонтологічного) змісту - національне законодавство» [9, с.103].

Як соціальний інститут «деонтологічні норми і відповідні етичні кодекси (кодекси етики, кодекси честі, деонтологічні кодекси) дають професіоналу орієнтири в соціальній практиці, підказують, як варто відповідати своїй соціальній функції, ролі, статусу при будь-яких професійних діях. Нормативноорієнтуючі соціальні інститути відіграють у суспільній практиці професійних груп роль механізмів морально-етичної орієнтації і регуляції поведінки. Їх мета - надати поведінці і мотивації моральної аргументації, етичної основи» [10, с.251].

Професійний етичний кодекс пропонує набір рекомендацій, які команди або організації можуть використовувати для прийняття правильних рішень на робочому місці. Це дозволяє встановити базові очікування щодо того, що є соціально прийнятним і як фахівці повинні підходити до проблем. Хоча створення та підтримка професійного етичного кодексу займає деякий час, це може допомогти працівникам працювати сумлінно та добросовісно, що може допомогти створити здорове робоче середовище.

Акти професійної етики встановлює обов'язкові правила поведінки, що відповідають моральним критеріям та традиціям юридичної професії, а також міжнародним стандартам та правилам професійної поведінки, яких усі фахівці повинні дотримуватися під час своєї професійної діяльності. До прикладів таких професійних кодексів у юридичній професії можна віднести: Бангалорські принципи поведінки суддів [11]; Загальний кодекс правил для адвокатів країн Європейського Співтовариства [12], Европейський кодекс поліцейської етики [13] тощо. В Україні діє Кодекс професійної етики судді [14], Кодекс професійної етики та поведінки прокурорів [15], Правила адвокатської етики [16].

Юристи зобов'язані дотримуватися професійного етичного кодексу, який існує незалежно від особливостей їх трудових відносин. Як вказує професор Жаровська I.M., обізнаність $з$ правовими приписами і вміння користуватися ними, у разі необхідності за- хищати всіма доступними шляхами» є складовими правової культури та правосвідомості [17, с.27].

Щоб діяти відповідально, вони повинні замислюватися про більш широкі наслідки своєї роботи, послідовно підтримуючи суспільне благо. Так, Правило 1.1 «Типових правил професійної поведінки Американської асоціації адвокатів» говорить: “Адвокат повинен надавати клієнту компетентне представництво. Для компетентного представництва потрібні юридичні знання, вміння, ретельність та підготовка, достатньо необхідні для представництва» [18].

\section{Висновок}

Отже, проведений аналіз дає можливість нам узагальнити, що кодекси професійної етики мають такі соціальні функції та цілі:

- визначають етичні вказівки та найкращі практики організації, яких слід дотримуватись для чесності, доброчесності та професіоналізму;

- містять норми превентивного та карального характеру, тобто для членів організації порушення етичного кодексу може призвести до санкцій, включаючи звільнення. Кодекси містить принципи, сформульовані як заяви про відповідальність, засновані на розумінні того, що суспільне благо завжди є першочерговим;

- регулюють ділову поведінку в межах професії та з іншими членами суспільства;

- визначають професійні ціннісні категорії;

- сприяють дотриманню професійної та службової дисципліни;

- сприяє очищенню професії, таким чином збільшуючи довіру до фахівців у галузі права, легітимізують юриспруденцію та практичну юридичну діяльність. Проілюструємо останне на прикладі. Кодекс професійної поведінки Британської Колумбiї у ст.2.1-5 (а) вказує, що адвокат повинен сприяти збереженню честі та чесності адвокатської професії, повинен викривати перед належними трибуналами без побоювань чи прихильності, непрофесійну чи нечесну поведінку будь -якого іншого адвоката і повинен без вагань здійснювати захист проти будь -якого адвоката, якого стверджують, що образив клієнта [19]. 


\section{Мітература}

1. Юридична деонтологія і професійна етика та логіка для юристів: навчально-методичний практикум для студентів денної та заочної форм навчання спеціальностей «Право» і «Міжнародне право». Тернопіль, 2019. 116 c.

2. Большакова О. В. Тенденції трансформації правосвідомості громадян у період перехідного розвитку українського суспільства: соціально-філософський аспект «Перспективи». Сочіально-політичний журнал. 2020. № 3. C. $37-43$

3. Гладчук Д. І. Деонтологічні засади поліцейської діяльності: зміст, сучасні вітчизняні стандарти Juris Europensis Scientia. 2020. №4. C. 10-14

4. Сливка С.С. Юридична деонтологія: підручник. Вид.6-те. К.: Атіка, 2015. 296 с.

5. Гапотій В.Д., Мінкова О.Г. Юридична деонтологія: навчальний посібник Мелітополь: ФОП Однорог Т.В., 2018. 146 с.

6. Кравчук В.М. Верховенство права як деонтологічний принцип юридичної практичної діяльності Украӥна в умовах ребормування правової системи: сучасні реалії та міжнародний досвід: [Матеріали V Міжнародної науково-практичної конференції, м. Тернопіль, Західноукраїнський національний університет, 16-17 квітня 2021 р.]. Тернопіль: ЗУНУ, 2021. 269 с.

7. Чупринський Б. О. Правова культура як основний складник професійної культури юриста. Науковий вісник Східноєвропейського начіонального університету імені Аесі Украйнки. 2013. №2. C.65- 70.

8. Бахновська І.П., Аалуєва А.О. Правосідомість юриста: шляхи формування. Порівняльно-аналітичне право. 2020. № 1.C. 20-23.

9. Пендюра М. М. Уніфікація норм поліцейської деонтології. Кафедра теорії держави та права: етапи становлення та перспективи розвитку: матеріали науково-теоретичної конференції (2 червня 2016 року) / редкол.: А. М. Завальний, Н. В. Аазнюк, Д. О. Тихомиров. Київ: НАВС, 2016. С. 101-104

10. Поліцейська деонтологія: навчальний посібник / за заг. ред. В. Я. Марковського. Аьвів: ЛьвДУВС, 2020. 316 с.
11. Бангалорські принципи поведінки суддів від 19.05.2006. Офіційний сайт ВРУ. URL: https://zakon.rada.gov.ua/laws/show/995_ j67

12. Загальний кодекс правил для адвокатів країн Європейського Співтовариства: Кодекс, Міжнародний документ від 01.10.1988. URL: https://zakon.rada.gov.ua/ laws/show/994_343\#Text

13. Європейський кодекс поліцейської етики: міжнародний документ Рекомендація Rec. (2001)10. Прийнята Комітетом міністрів Ради Європи 19 вересня 2001 року. 59 c. URL: http://pravo.org.ua/files/Criminal\%20 justice/rec1.pdf

14. Кодекс професійної етики судді: затв. V з'їздом суддів України 24.10.2002 URL: https://zakon.rada.gov.ua/rada/show/n000441502\#Text

15. Кодекс професійної етики та поведінки прокурорів: затв. Всеукр. конфер. прокурорів 27.04.2017 URL: https://zakon.rada.gov.ua/laws/show/n000190017\#Text

16. Правила адвокатської етики: затв. Звітно-виборним з'їздом адвокатів України від 09.06. 2017 p. URL: https://zakon.rada.gov. ua/rada/show/n0001891-17\#Text

17. Жаровська I.M. Доступність права: теоретико-правові проблеми:[Монографія]. Аьвів: вид. АКА. 208 с.

18. Model Rules of Professional Conduct 2020 by the American Bar Association. URL: https://www.americanbar.org/groups/ professional_responsibility/publications/model_ rules_of_professional_conduct/model_rules_of_professional_conduct_table_of_contents/

19. Code of Professional Conduct for British Columbia. 2013. Chapter 2 - Standards of the Legal Profession awsociety. URL: bc.ca/ support-and-resources-for-lawyers/act-rulesand-code/code-of-professional-conduct-forbritish-columbia/chapter-2---standards-of-thelegal-profession/

\section{DEONTOLOGICAL LEGAL AWARENESS OF A LAWYER IN THE LABOR SPHERE}

Annotation. The article is devoted to the deontological legal consciousness of a lawyer. It is indicated that legal awareness expands a 


\section{Філософія та психологія права}

\section{АНОТАЦІЯ}

Статтю присвячено деонтологічній правовій свідомості юриста. Вказано, що правосвідомість розширюе можливості особи щодо реалізачіӥ правових норм. Правосвідомість допомагае пропагувати свідомість правової культури, бере участь у бормуванні законів $i$ верховенства правa.

Узагальнено, що правова свідомість визначається як процес, за допомогою якого люди осмислюють свій досвід, спираючись на правові категорї та концепиій. Ї̈ в наукових колах прийнято розуміти як борму відображення правових явищ, яка включає психічні, інтелектуальні, емочійні й вольові процеси та стани. Вказано, що деонтологічна правосвідомість бормується шляхом накопичення та бункиіональної взаємодї багатьох елементів.

Мотивовано, щзо юридична деонтологія $\epsilon$ теоретичною основою для створення актів деонтологічного змісту иляхом імплементаииї високих норм професійної етики. Вони мають подвійне значення: 3 одного боку, деонтологічна правосвідомість у трудовій сфьері збагачує особу юриста, допомагае належно реалізовувати свої пробесійні фбункиї, захищати інтереси прав та свобод громадян. 3 іншого боку, деонтологічна правосвідомість покликана унібокувати трудові відносини серед юридичних фбахівців, зробити професію правника моральною, доброю, справедливою.

У висновку вказано, що кодекси професійноі етики мають такі соціальні функциї та иілі: визначають етичні вказівки та найкращі практики організаиій, яких слід дотримуватись для чесності, доброчесності та професіоналізму; містять норми превентивного та карального характеру, тобто для иленів організаиї порушення етичного кодексу може призвести до санкиій, включаючи звільнення. Кодекси містять принизипи, сбормульовані як заяви про відповідальність, засновані на розумінні того, що суспільне благо завжди є першочерговим; регулюють ділову поведінку в межах професї та з іншими иленами суспільства; визначають професійні иіннісні категорї; сприяють дотриманню пробесійної та службової дисципліни; сприяє очищенню професіи, таким чином збільшуючи довіру до фахівијі у галузі права, легітимізують юриспрудениію та практичну юридичну діяльність.

Ключові слова: деонтологія, правосвідомість, пробесійна етика юриста, кодекси професійної етики, трудові відносини, корпоративні норми права. person's ability to implement legal norms. Legal awareness helps to promote the consciousness of legal culture, participates in the formation of laws and the rule of law.

It is generalized that legal consciousness is defined as a process by which people comprehend their experience based on legal categories and concepts. It is understood in scientific circles as a form of reflection of legal phenomena, which includes mental, intellectual, emotional and volitional processes and states. It is indicated that deontological legal consciousness is formed through the accumulation and functional interaction of many elements.

It is motivated that legal deontology is a theoretical basis for the creation of acts of deontological content through the implementation of high standards of professional ethics. They have a double meaning: on the one hand, deontological legal awareness in the labor sphere enriches the personality of a lawyer, helps to properly implement their professional functions, protect the interests of the rights and freedoms of citizens. On the other hand, deontological legal awareness is designed to unify labor relations among legal professionals, to make the legal profession moral, good, fair.

The conclusion states that codes of professional ethics have the following social functions and goals: identify ethical guidelines and best practices of the organization, which should be followed for honesty, integrity and professionalism; contain rules of preventive and punitive nature, ie for members of the organization violation of the code of ethics can lead to sanctions, including dismissal. Codes contain principles formulated as statements of responsibility based on the understanding that the public good is always paramount; regulate business behavior within the profession and with other members of society; determine professional value categories; contribute to the observance of professional and service discipline; contributes to the purification of the profession, thus increasing trust in legal professionals, legitimize jurisprudence and practical legal activities.

Key words: deontology, legal awareness, professional ethics of a lawyer, codes of professional ethics, labor relations, corporate law. 